$\sqrt{B}$

J. Bio-Sci. 25: 1-7, 2017

ISSN 1023-8654

http://www.banglajol.info/index.php/JBS/index

\title{
MICROBIOLOGICAL QUALITY ASSESSMENT OF RAW SALAD VEGETABLE SOLD IN MINNA METROPOLIS, NIGERIA
}

\author{
JD Bala*, FA Kuta, NU Adabara, AS Adedeji, UM Oyedum and G Murtala \\ Department of Microbiology, School of Life Sciences, Federal University of Technology, Minna, Nigeria
}

\begin{abstract}
Vegetables are edible part of plants. A total of twenty five raw salad vegetables were collected and the microbiological assessment was made using pour plate method. The analysis was carried out on carrots, cucumber, cabbage, lettuce and tomatoes. The results obtained from this study revealed that the total heterotrophic viable bacterial counts, coliform counts and fungal counts for all the salad vegetables ranged from $1.4 \times 10^{6}-6.2 \times 10^{6} \mathrm{cfu} / \mathrm{g}, 1.1 \times 10^{6}-3.3 \times 10^{6} \mathrm{cfu} / \mathrm{g}$ and $2.1 \times 10^{3}-4.5 \times 10^{5}$ cfu/g respectively. The data were subjected to One Way Analysis of Variance (ANOVA) test which showed that there was significant difference $(p<0.05)$ in the microbial load of each of the raw salad vegetables samples. The microbial isolates identified were E. coli, Staphylococcus aureus, Bacillus subtilis, Klebsiella sp., Pseudomonas sp., Aspergillus niger, Mucor sp., Penicillium sp., Aspergillus flavus and Fusarium sp. Staphylococcus aureus and Aspergillus niger were predominant. This suggests that salad vegetables used in this study are of public health concern because, they harbours microorganisms that could be hazardous to human health. Hence consumers should practice appropriate hygiene during the preparation of salad for consumption.
\end{abstract}

Key words: Assessment, microorganisms, quality, raw salad, vegetables

\section{Introduction}

Vegetables are considered as the leafy outgrowth of plants or plants shoot used as food. These include those plants or plant part used in making soup or served as an integral part of main meal (Yusuf et al. 2004). Vegetables can also be regarded as the edible component of plants, such components includes leaves, stalk, roots, tubers, bulbs, flowers and seed (ICMSF- International Commission on Microbiological Specification for Foods, 1974). Vegetables are important protective food and highly beneficial for the maintenance of health and prevention of diseases. They contain valuable food ingredients which are essential for the proper function of the body. Vegetable contain various medicinal and therapeutic agent and are valued mainly for their high vitamin and mineral content (Yusuf et al. 2004). Studies have evaluated the association of vegetables consumption with the reduction of risk of specific diseases (Hung et al. 2004). The occurrence of microorganisms in vegetables may be expected to reflect the sanitary quality of the processing steps and the microbiological condition of the raw product at the time of processing. Vegetables contamination in the field has been recognized as a source of human infection. Many of the viruses, bacteria and protozoan on vegetables which have caused food poisoning are derived from human feces ( $\mathrm{Ho}$ et al. 1989, Rosenblum et al. 1990).

Foods, microorganisms and humans are in a long and interesting association that developed long before the beginning of recorded history. Foods are not only of nutritional value to those who consume them but often are ideal culture media for microbial growth (Willey et al. 2008). Vegetable which is defined as "any of the various plants especially herbaceous plants used wholly or partly for food" (Thomas 1995). Some of these

*Author for correspondence: bala.jeremiah@futminna.edu.ng/ jerrybrown316@yahoo.com 
vegetables are cooked while others are eaten raw such as carrots, cabbage and lettuce. Some of these vegetables are grown with application of manure, fertilizer, and irrigation water which may serve as possible sources for contamination of the vegetables (Buck et al. 2003). Minimally processed ready-to-eat vegetables consist of raw vegetables that have been washed, peeled, sliced, chopped and shredded. Salads may be served with or without dressings depending on the consumer. For many types of raw or minimally processed foods, the microbial load is often composed of mixed species (Schuenzel and Harrison 2002). The washing process of vegetables reduces the microbial load approximately 10 folds thereby prolonging the shelf life (Gracia-Gimeno and Zurera-Cosano 1997). The survival and growth of pathogens on fresh product like vegetables is influenced by the organism, the product and the environmental conditions in the field and there after including storage conditions (Birbeck 2004). Environmental conditions can greatly influence microbial population due to the presence of free moisture on leaves from precipitation, dew or irrigation which may promote survival and growth of microbial pathogens (Brock and Lindow 1999). During vegetable handling, the process of washing and shredding can transfer microorganisms. Pathogenic microorganisms are able to infiltrate cracks, crevices and intracellular spaces of food products.

However, pathogenic microorganism of human origin may also be present in minimally processed vegetables as the minimal technological processing may be unable to remove the original contamination resulting from air, soil, water, insects, animals, workers, harvesting and transportation equipment. Certain fungi such as Aspergillus, Fusarium, and Penicillium sp. as commonly occurring filamentous fungi grow in vegetable and their growth may result in production of toxins known as mycotoxins, which can cause a variety of ill effect in human from allergic responses to immunosuppression and cancer (Pitt et al. 1998).

Microbial growth on raw vegetables can result in the formation of biofilms by spoilage microorganisms which could provide protective environment for pathogens and reduce the effectiveness of sanitizers and other inhibitory agents. For example Listeria monocytogene in a multi species biofilm with Staphylococcus aureus has been reported to be essentially unaffected by treatment with 500 ppm chlorine (Ketchum 2002). Biofilms have been observed on numerous leaf surfaces including leaves of lettuce and cabbage (Morrisa and Monier 1997).Fresh cut vegetables are considered a potential hazard since the occurrence of pathogens cannot be excluded and the product is consumed without heating. Thus, ready-to-eat salad vegetables could be a potential pathogen source if not hygienically processed before consumption.

So far to the best of our knowledge, efforts have been geared towards studying the nutritional constituents of salad vegetables. As such there seem to be dearth of information on the microbiota been documented proving that a well-developed understanding of these is needed. Therefore, this study represents one of the few studies in this area. This will provide an insight to the microbiological characteristics of salad vegetables so as to lay a foundation of the microbiological aspects of salad vegetables in order to enhance better understanding of the microorganisms associated with salad vegetables particularly some pathogenic microbes that could cause health hazard and human diseases. Thus the study was designed particularly to determine the quality and microorganisms associated with salad vegetables in Minna, Niger state, Nigeria.

\section{Materials and Methods \\ Collection of samples}

A total of twenty five different raw salad vegetables were obtained from five different vendors. The samples included cabbage, tomatoes, cucumber, lettuce, and carrots ( 5 each) which were all obtained from different road side vendors within Minna, metropolis, Nigeria. All the samples were collected in sterile plastic bags and transported to the laboratory for processing immediately after collection. 


\section{Methodology and preparation of samples}

The pour plate method was used as described by Jolt (2003) where $1 \mathrm{ml}$ of the appropriate serially diluted sample was transferred into labeled, well cleaned sterile Petri dish and molten agar medium $(20 \mathrm{ml})$ poured. Poured plates were swirled gently to allow for proper distribution of colonies.

\section{Bacteriological analysis}

\section{Total heterotrophic viable bacterial count}

The method of Jolt (2003) was used where a 10 fold serial dilution of the samples was carried out. One gram of each of the salad vegetable was aseptically weighed and added into a sterile test tubes containing $9 \mathrm{ml}$ of sterile, distilled water (deionized water). The test tubes were well shaken to mix together the content. Serial dilution was carried out using the mixed sterile distilled water as diluents. The 10-fold serial dilution was made by aseptically transferring $1 \mathrm{ml}$ of the mixed distilled water in the test tubes into sterile test tubes containing $9 \mathrm{ml}$ of sterile, distilled water. This gave ten times dilution. Subsequent dilutions were made from the aforementioned dilution. About $1 \mathrm{ml}$ of the sample was pipette out from the $10^{-6}$ and $10^{-8}$ dilution tube into well labeled petri dishes. Then $20 \mathrm{ml}$ of the molten nutrient agar was added into each plate and swirled gently to allow for proper mixing. The plates were incubated for $24 \mathrm{~h}$ at $37^{\circ} \mathrm{C}$. Then the colonies develop on the plates were counted using a colony counter and expressed as colony forming unit per gram (cfu/g). The sample from each vendor was examined in triplicates and the average was recorded. The colonies differing in size, shape and colour were selected from the different plates on nutrient agar and sub-cultured repeatedly to obtain pure isolates. Macconkey agar was used to determine coliform counts. The pure isolates were maintained on agar slant for further characterization and identification.

\section{Mycological analysis}

The fungal count was carried out by pipetting $1 \mathrm{ml}$ of the serially diluted salad vegetable onto Sabouraud Dextrose Agar (SDA) containing $0.01 \%$ chloramphenicol. An appropriate dilution of $10^{3}$ was used using pour plate method as described by Jolt (2003). The plates were incubated for 3 days at $25^{\circ} \mathrm{C}$.

\section{Characterization and identification of isolates}

\section{Bacterial isolates}

The characterization and identification of the bacterial isolates were carried out based on cell morphology, Gram's reaction and biochemical tests according to methods described by Jolt (2003) and Oyeleke and Manga (2008). The isolates were identified by comparing with those of known taxa using the schemes of Cao (1996).

\section{Fungal isolates}

The mould isolates were characterized based on the colour of aerial and substrate hyphae, type of hyphae, shape and kind of asexual spores, presence of foot cell, sporangiophore, conidiophores, and the characteristics of spore head. A small portion of the mycelia growth was carefully picked with the aid of a sterile inoculating needle and placed in a drop of lactophenol cotton blue on a microscopic slide and covered with a cover slip. The slide was examined under the microscope, first with $(\times 10)$ and then with $(\times 40)$ objective lens to detect the spores and some special structures of the fungi. The isolates were identified by comparing their characteristics with those of known taxa using the schemes of Domsch and Gams (1970). 


\section{Results}

\section{Microbial counts}

The results obtained for total viable bacterial counts, total coliform counts and total fungi counts for all the salad vegetables obtained in the present study ranged from $1.4 \times 10^{6} \mathrm{cfu} / \mathrm{g}-6.2 \times 10^{6} \mathrm{cfu} / \mathrm{g}, 1.1 \times 10^{6} \mathrm{cfu} / \mathrm{g}$ $3.3 \times 10^{6} \mathrm{cfu} / \mathrm{g}$ and $2.1 \times 10^{3} \mathrm{cfu} / \mathrm{g}-4.5 \times 10^{5} \mathrm{cfu} / \mathrm{g}$ respectively (Table 1 ).

\section{Frequency of occurrence of microorganisms isolated from salad vegetables}

Table 2 revealed the frequency of occurrence of microbial isolates. Staphylococcus aureus and Aspergillus niger had the highest frequency of occurrence of 24.0 and 18.5 respectively.

Table 1. Total Microbial counts of the isolates.

\begin{tabular}{lccc}
\hline \multicolumn{4}{c}{ Microbial counts (cfu/g) } \\
\hline Samples & Total coliform & Total viable & Total fungi \\
\hline Cucumber & $1.3 \times 10^{6 \mathrm{ab}}-3.3 \times 10^{6 \mathrm{a}}$ & $2.3 \times 10^{6 \mathrm{bc}}-6.2 \times 10^{6 \mathrm{a}}$ & $2.1 \times 10^{3 \mathrm{c}}-6.3 \times 10^{4 \mathrm{c}}$ \\
Carrot & $1.1 \times 10^{6 \mathrm{c}}-2.2 \times 10^{6 \mathrm{a}}$ & $2.8 \times 10^{6 \mathrm{c}}-3.0 \times 10^{6 \mathrm{c}}$ & $1.8 \times 10^{5 \mathrm{~b}}-4.5 \times 10^{5 \mathrm{a}}$ \\
Cabbage & $1.2 \times 10^{6 \mathrm{bc}}-3.2 \times 10^{6 \mathrm{a}}$ & $1.4 \times 10^{6 \mathrm{c}}-2.1 \times 10^{6 \mathrm{c}}$ & $1.9 \times 10^{4 \mathrm{c}}-1.2 \times 10^{5 \mathrm{~b}}$ \\
Lettuce & $2.1 \times 10^{6 \mathrm{a}}-2.2 \times 10^{6 \mathrm{a}}$ & $1.4 \times 10^{6 \mathrm{~d}}-2.8 \times 10^{6 \mathrm{a}}$ & $5.0 \times 10^{4 \mathrm{c}}-1.2 \times 10^{5 \mathrm{~b}}$ \\
Tomato & $2.0 \times 10^{6 \mathrm{ab}}-3.1 \times 10^{6 \mathrm{a}}$ & $1.8 \times 10^{6 \mathrm{bc}}-2.0 \times 10^{6 \mathrm{c}}$ & $2.1 \times 10^{3 \mathrm{~d}}-1.2 \times 10^{4 \mathrm{c}}$ \\
\hline
\end{tabular}

Values on the same column with different superscript $(a . b, c, d)$ are significantly different from each other $(p<0.05)$ while those with the same superscript $(a, b, c, d)$ are not significantly different from each other $(p>0.05)$.

Table 2. Frequency of occurrence of microorganisms isolated from salad vegetables.

\begin{tabular}{lcc}
\hline Organisms & No of occurrence & Frequency of occurrence (\%) \\
\hline Klebsiella sp. & 04 & 7.40 \\
Bacillus subtilis & 08 & 14.8 \\
Staphylococcus aureus & 13 & 24.0 \\
Escherichia coli & 05 & 9.30 \\
Aspergillus niger & 10 & 18.5 \\
Mucor sp. & 04 & 7.40 \\
Aspergillus flavus & 03 & 5.60 \\
Pseudomonas sp. & 02 & 3.70 \\
Fusarium sp. & 03 & 5.60 \\
Penicillium sp. & 02 & 3.70 \\
\hline Total & 54 & $100 \%$ \\
\hline
\end{tabular}




\section{Discussion}

The results of the present study revealed that there was remarkable bacteria and fungi contamination of different salad vegetable samples. The samples were contaminated with varying degrees of pathogenic bacteria and fungi. The bacterial isolates identified in the present study include; Escherichia coli, Staphylococcus aureus, Pseudomonas sp, Bacillus subtilis. and Klebsiella sp. The bacterial count in general, ranged from $1.1 \times 10^{6} \mathrm{cfu} / \mathrm{g}-6.2 \times 10^{6} \mathrm{cfu} / \mathrm{g}$ and the fungal count ranged from $2.1 \times 10^{3} \mathrm{cfu} / \mathrm{g}-4.5 \times 10^{5}$ cfu/g. This is in agreement with the report of Adebayo et al. (2012) who also reported similar microbial counts. The high count of bacteria detected in salad vegetables in the present study may be due to improper handling during harvesting and transportation. In the present study, all the vegetables examined harbored Staphylococcus aureus, while other microorganisms include Bacillus subtilis, Klebsiella sp., E. coli and Pseudomonas sp.

Most strains of Staphylococcus aureus are known to be pathogenic due to the heat stable enterotoxin they produce. The presence of Staphylococcus aureus, a pathogenic organism of public health concern and significance in these vegetables might have contaminated the vegetables from source as a result of handling by farmers or retailers. During processing, contamination could arise by use of dirty hands or clothing by food handlers and utensils used in slicing or keeping the vegetables. Improper handling and improper hygiene might lead to the contamination of food and this might eventually affects the health of the consumers (Omemu and Bankole 2005, Mgbakor et al. 2011).

The detection of $E$. coli in the study revealed poor hygienic standard in the handling of these raw salad vegetables or it could also be from contamination during harvest, it can also be present in water using in washing the salad vegetables. Presence of $E$. coli indicates recent contamination by faecal matter and possible presence of other enteric pathogens known to be causative agents of food borne gastroenteritis and bacterial diarrhea disease (Adebayo et al. 2012).

The fungal isolates obtained in the present study include, Aspergillus niger. Aspergillus flavus Fusarium sp, Mucor sp and Penicillium sp. The presence of these fungi in raw salad vegetables have been reported in previous studies (Akintobi et al. 2011, Al-Hindi et al. 2011). Generally, fungi are considered toxigenic or pathogenic (Al-Hindi et al. 2011). During refrigeration, some moulds may produce mycotoxins on raw salad vegetables (Al-Hindi et al. 2011). Pathogenic fungi, on the other hand, could cause infections or allergies (Monso 2004, Al-Hindi et al. 2011). Aspergillus sp are known to produce several toxic metabolites, such as aflatoxin, malformins, naphthopyrones and they can produce ochratoxins (OTA), a mycotoxin which is a very important toxin worldwide because of the hazard it poses to human and animal health thus extra care should be taken during personnel handling of these vegetable, harvesting, cleaning, sorting, packaging, transport and storage (Pitt et al.1998, Petzinger and Weidenbach 2002, Al-Hindi et al. 2011). The result of the present study shows that the salad vegetables were contaminated by potentially pathogenic microbes. Therefore, salad vegetables could be a source of infection to the consumers if not properly washed before consumption (Al-Hindi et al. 2011).

\section{Conclusion}

The results of the present study revealed that the salad vegetables were all contaminated by a wide variety of potential pathogenic microorganisms. Proper hand wash with warm water and soap before handling the vegetable should be encourage. The vegetable should be thoroughly washed with clean water during the process of preparation. Food handlers should be advised on the need for good hygiene and the use of potable water for the washing of these vegetables to reduce the microbial load as low as possible. 


\section{References}

Adebayo TBC, Odu NN, Esen CU and Okonko IO (2012). Microorganisms Associated With Spoilage of Stored Vegetables in Uyo Metropolis, Akwa Ibom State, Nigeria, Nigeria Journal of Microbiology 10(3): 23-32.

Akintobi AO, Okonko IO, Akano OR, Agubiade SO and Onianwa O (2011). Isolation and identification of fungi associated with the spoilage of some selected fruits in Ibadan, South Western Nigeria, Academia Arena 3(11): 1-10.

Al-Hindi RR, Al-Najada AR and, Mohamed SA (2011). Isolation and identification of some fruit spoilage fungi: Screening of plant cell wall degrading enzymes, African Journal of Microbiology Research 5(4): 443-448.

Birbeck J (2004). The forgotten vitamin, New Zealand Journal of Commercial Grower 7(18): 39-50.

Brock TD and Lindow MT (1999). Biology of Microorganisms, 5th Ed., Academic Press, London, 195 pp.

Buck JW, Walcott RR and Buechat LR (2003). Recent trends in Microbiological safety of Fruits and Vegetables, American Journal of Clinical Nutrition 31: 142-159.

Cao G (1996). Antioxidant capacity of tea and common vegetables, Journal of Agricultural Foods and Chemical 44: 3426 3431.

Domsch KH and Gams W (1970). Fungi in agricultural soil, 1st Ed., Longman group limited, London, 12-15 pp.

Garcia-Gimeno RM and Zurera-Cosano G (1997). Ready- to- eat vegetable Salad shelf life, Journal of Food Microbiology 6: $72-79$.

Ho JL, Shands KN, Freidland G, Eckind P and Fraser DW (1989). An outbreak of type 46 Listeria monocytogenes Infection involving Patients from Eight Boston Hospital, Archives of Internal Medicine 146: 520-524.

Hung HC Joshipura KJ, Jiang RH, Hunter D and Smith SA (2004). Fruits and Vegetable intake and the risk of major chronic disease, Journal of National Cancer Institute 95: 157-164.

International Commission on Microbiological Specification for Foods (ICMSF) (1974). Microorganisms in food. Sampling for microbiological analysis. Principles and specific applications. Recommendations of the international commission on microbiological specification for foods of the international association of microbiological societies. Toronto.

Jolt DI (2003). Diacetyl test as quality control tool in processing vegetable Salad, Food Technology 58: 90.

Ketchum P (2002). Microbiology concepts and applications, Journal of Foods Protection 58(10): 1129.

Mgbakor C, Ojiegbe GC, Okonko IO, Odu NN, Alli JA, Nwanze JC and Onoh CC (2011). Bacteriological evaluation of some sachet water on sales in Owerri metropolis, Imo State, Nigeria, Malaysia Journal of Microbiology 7(4): 217225.

Monso EM (2004). Occupational asthma in greenhouse workers, Current Opinion in Pulmonary Medicine 10: 147-150.

Morrisa CE and Monier JE (1997). Methods of observing microbial biofilm on leaf sufaces, Journal of Applied Environmental Microbiology 5: 123-129.

Omemu AM and Bankole MO (2005). Ready-to-eat (RTE) vegetable salad: effect of washing and storage temperature on the microbial quality and shelf-life. In: the Book of Abstract of the 29th Annual Conference \& General Meeting (Abeokuta 2005) on Microbes As Agents of Sustainable Development, Organized by Nigerian Society for Microbiology, UNAAB, 6-10th Nov., 28 pp.

Oyeleke SB and Manga SB (2008). Essentials of Laboratory Practicals in Microbiology. Tobest Publisher, Minna, Nigeria, 36-75 pp.

Petzinger E and Weidenbach A (2002). Mycotoxins in the food chain: The role of ochratoxins, Live Stock Production Science $76: 245-250$. 
Pitt JI, Hocking AD, Miscamble BF, Dharmaputra S, Kuswanto KR, Rahayu ES and Sardjono(1998). The mycoflora of food commodities from Indonesia, Journal of Food Mycology 1(1): 41-60.

Rosenblum LS, Mirkin IR, Allen FT, Safford S and Haller SC (1990). A trace to community distributed lettuce, American Journal of Public Health 80: 1075-1079.

Schunzel, KM and Harrison MA (2002). Microbial antagonist of food borne Pathogens on fresh, minimally processed vegetables, Journal of Food Protection 2: 225-238.

Thomas S (1995). The Oxford Dictionary and Thesaurus, 17th Ed., Oxford University press, London.

Willey JM, Sherwood LM and Woolverton CJ (2008). Prescott, Harley and Klein's Microbiology 7th Ed., McGraw Hill, New York, 1023-1046 pp.

Yusuf IZ, Oyaweye OM, Yongabi KA and Pemu AT(2004). Bacteriological quality assessment of salad vegetables sold in Bauchi Metropolis, Nigeria Journal of Microbiology 18: 316-320. 
